\title{
The Skill of Making a Decision and its Relationship of Academic Achievement Among Students
}

\author{
https://doi.org/10.3991/ijes.v9i4.26363 \\ Ban Hassan Majeed ${ }^{(凶)}$ \\ University of Baghdad, Baghdad, Iraq \\ ban.h.meihcoedu. uobaghdad.edu.iq
}

\begin{abstract}
This research aims to know the essence of the correlation between decision-making skills and academic achievement among students of computer science departments in the colleges of education in the province of Baghdad. The size of the research sample from the two colleges in Baghdad governorate was (200) male and female students, distributed among (104) male and (96) female students. To measure the decision-making skill and academic achievement, the researcher built two tests, the first to measure the decision-making skill, and the second an achievement test in numerical analysis scheduled for second-year students of the Department of Computer Science, and the validity and reliability of each test were verified. After collecting and analyzing the data, the researcher concluded that the students of the computer science departments in the colleges of education in Baghdad governorate have the decision-making skill compared to the hypothetical average that was compared, while the female students outperformed the male students in the decision-making skill test that was prepared for this research. While their achievement was good compared to the hypothetical average that was compared, female students outperformed male students in the achievement test for the subject of numerical analysis. There is a correlation between decision-making skill and the academic achievement of students as a whole. However, there is no correlation between decision-making skill and students' academic achievement, while there is an inverse relationship between decision-making skill and student achievement. Accordingly, the research reached several recommendations.
\end{abstract}

Keywords—decision-making skill, academic achievement

\section{Introduction}

The amount of knowledge the learner possesses is no longer a true indicator of his success in facing the problems that he faces in his academic or practical life, but rather the subject of his potential to participate effectively in the production of knowledge, how to use it, apply it and employ it when needed in solving these problems is the basis [1]. Therefore, teaching thinking, its skills, methods, and what is built upon in making decisions and solving problems have become an urgent need than ever before in the learning and teaching process, as this helps students to strengthen the judgment 
of causes, evidence, and evidence, and to determine the criteria upon which the evaluation judgment is based, which helps them to enhance their capabilities in the areas of making decisions and problem solving [2,3]. The issue of thinking and its impact on making the right decisions has raised a lot of controversy among researchers in addition to its importance in teaching and learning mathematics and the need for each of them to determine how the learner distinguishes the right decisions to solve a mathematical problem and the impact of all this on their achievement in mathematics [4,5]. This is what caught the attention of the researcher, as through her work in the Department of Computer Science and the frequent complaints of students about their inability to employ the numerical analysis subject they are studying as a prerequisite in the second stage in programming the proposed solutions to mathematical problems that need to make the right decisions regarding the best-proposed solutions and the impact of each That is on their low achievement in that article. The researcher decided to study this problem and to know the nature of the correlation between the decision-making skill and the achievement of second-stage students in the computer science departments in the faculties of education in the subject of numerical analysis on the other hand [6].

\section{Importance of research}

\subsection{Theoretical and applied importance}

The decision-making skill is considered as one of the higher-order thinking skills that the learner needs in his academic and personal life to judge the reasonableness of the results and to choose the appropriate alternative from among several suggested alternatives. The achievement test is of great importance, as though it is possible to know the extent to which the objectives set have been achieved, and thus the strengths and weaknesses of students can be known. The research draws the attention of those in charge of the educational process to increasing interest in the concept of decision-making skill and working to encourage it among students so that they can achieve high levels of academic achievement. The results of the research may help those interested in the educational process and researchers to design various training extension programs aimed at developing decision-making skills to increase academic achievement among students in schools and universities.

\subsection{Research objective and hypotheses}

The skill of decision-making among students of computer science departments in the colleges of education in the province of Baghdad. The achievement level of students of computer science departments in the colleges of education in Baghdad governorate in the subject of numerical analysis. The nature and direction of the correlation between decision-making skill and academic achievement among students of computer science departments in the colleges of education in Baghdad governorate, and its nature according to the gender variable. Hypotheses were formulated as in 2.2.1, and will be mentioned in the interpretation of the results. 


\section{Hypotheses.}

1. There is no statistically significant difference at the significance level $(0.05)$ between the average real performance and the average hypothetical performance of, the second stage students/Computer Science Departments/Colleges of Education/Baghdad Governorate in the decision-making skill test preparation for the purposes of this research.

2. There is no statistically significant difference at the significance level (0.05) between the average performance scores of second-year students/Computer Science Departments/Colleges of Education/Baghdad Governorate in the prepared decision-making skill test.

3. There is no statistically significant difference at the significance level (0.05) between the mean real performance and the mean performance hypothetical, for the second stage students/Computer Science Departments/Colleges of Education/Baghdad Governorate in the achievement test preparation for the purposes of this research.

4. There is no statistically significant difference at the significance level (0.05) between the average performance scores of second-year students/Computer Science Departments/Colleges of Education/Baghdad Governorate in the prepared achievement test.

5. There is no correlation between the decision-making skill and achievement at the significance level (0.05), among the second stage students/Departments of Computer Science/Colleges of Education/Baghdad Governorate.

6. There is no correlation between the decision-making skill and achievement at the significance level (0.05), among the second stage students in the Computer Science Departments/Colleges of Education/Baghdad Governorate.

7. There is no correlation between the decision-making skill and achievement at the significance level (0.05), among second-year female students in the Departments of Computer Science/Colleges of Education/Baghdad Governorate.

\subsection{Research terms}

It is "a mental process that requires a great deal of attention and awareness to diagnose, analyze and study the problem [7]. Working on choosing the best alternatives after studying the consequences of each alternative or option and its impact on the objectives to be achieved [8,9]. The researcher defines it procedurally as "the ability of second-year students in the computer science departments in the colleges of education in Baghdad governorate to respond to the paragraphs of the test of decision-making skill in mathematics prepared by the researcher for this research, and it is measured by the total score they obtain on this test". In [10], it describes the outcome of what the student learns after some time, and it can be measured by the degree he obtains in an achievement test, to determine the extent of the success of the strategy that the teacher sets and plans to achieve his goals, and the knowledge that the student reaches is translated into grades. The outcome of what the student learns after a period, which can be measured by the score he obtains in an achievement test, to know the extent of the success of the strategy that the teacher sets and plans to achieve his goals, and the 
knowledge that the student reaches is translated into grades [11,12]. The researcher defines it procedurally as "the amount that the students of the research sample obtain from the components of mathematical knowledge: information, knowledge, concepts, principles, generalizations, skills and methods of thinking in the subject of numerical analysis, measured by the total degree that they obtain through their responses to the paragraphs of the achievement test preparation for this research".

\section{Theoretical background and previous studies}

\subsection{Decision-making skills}

The concept of decision-making is almost related to the concept of problem-solving, but many educators and theorists consider that the concept of decision-making is the last link in problem-solving. Some researchers describe decision-making as part of thinking strategies that include problem-solving because it includes steps and processes that are distinct from each other [13]. Because problem-solving is a basic requirement in an individual's life, many of the situations that a person faces in his daily life are mainly situations that require problem-solving. Students learn to solve problems to be able to make sound decisions in their lives. If the individual's life was of a fixed nature, and each had a specific role to play in it, the issue of problem-solving would not be an urgent issue today, and thus learning to solve problems becomes extremely important [14]. Mathematics is considered one of the branches of knowledge that works to develop thinking and the ability to solve problems and is characterized by the logical and cumulative interrelated structure. It is distinguished by its structural nature that allows the student to conclude more than one logical result of the same premises given, as well as its inferential structure that allows flexibility in the method of organizing the content, as well as The subject of mathematics is rich in problem situations that enable students to search for multiple and varied solutions, and give the opportunity to objectively critique problem situations, and this gives students flexibility in thinking patterns and performance strategies $[15,16]$. Some researchers classify the decision-making process within the thinking strategies that include solving problems and forming concepts in addition to the decision-making process, and they deal with each of them independently, because it includes steps and processes distinct from each other. While others see that the decision-making process is identical to the problem-solving process, considering that problems are nothing but situations that require decisions about solutions to these problems [17]. The decision-making process includes a set of commonalities among them, which are: the existence of a problem or issue that needs to be taken, the availability of a set of organized procedures according to a logical approach that the decision-maker is supposed to follow, and the use of a set of mental processes and skills when making a decision, and generating A set of alternatives and solutions aimed at solving the problem, and then taking the appropriate decision, and the decision-making process is affected by the personal values in which the decision-maker believes, and the experience that the individual went through plays an important role in making the appropriate decision, and working on evaluating the alternatives and options available to the decision-maker according to Criteria on which 
to base. The decisions taken by the individual may be arbitrary and may be rational and deliberate in light of the available information $[18,19]$. If the teacher wants to help his students make logical decisions themselves, then he must offer them alternatives that they can understand their consequences, because without that understanding they do not make a logical decision, and with the continuation of the training, the number of alternatives and the degree of their complexity can increase to enhance their self-confidence and their ability to make the right decisions [20,21].

\subsection{Academic achievement}

Academic achievements are of great importance in the life of the individual and his family, as it is not only successfully passing successive stages of study and obtaining the grades that qualify him for that, but has very important aspects in his life as it is the compulsory path for choosing the type of study and profession, and thus determining the social role that will take place [22]. By the individual, the social status he will achieve, his view of his abilities, his sense of success, and his level of ambition. Mathematics achievement receives great attention from educators and parents due to the prevailing belief in the close relationship linking achievement in mathematics with the ability to think and solve problems [23]. Student achievement and imparting them to specific knowledge and skills are among the priorities of educational institutions, and the mirror that reflects their outcomes. Therefore, measuring achievement constitutes one of the important sources for identifying the outcomes of educational processes, and providing those in charge of the education sectors with the necessary information necessary to make educational decisions such as passing, failing, classifying students according to their levels of achievement, or introducing students with low achievement into remedial programs. The results of measuring achievement can also be used in making decisions related to the administrative system of educational institutions [24,25]. Whereas the university is one of the important educational institutions that reflects the extent of society's pursuit of development and development, and it is one of the main means that achieve the goals and objectives of education. Therefore, the university and the colleges, institutes, branches, and departments it contains should focus on identifying the capabilities of its students, their attitudes and tendencies to develop those abilities, trends, and tendencies and enable students to invest their energies and the knowledge they acquire to the fullest possible extent [26,27]. states that academic achievement is what a student can do after completing the study of a program, or a specific curriculum, and this concept includes the competence and knowledge that the student acquired after graduating as a result of studying a set of different curricula and study materials [28]. From the above, we note that achievement is related to the overall score, result, or level that the student attains as a result of performing a specific test. Accordingly, it can be said that achievement is one of the most important characteristics that distinguish the student from other students, and through it, he can know the extent of the student's progress, and his acquisition of concepts, generalizations, and skills [29,30]. 


\section{$4 \quad$ Methods}

\subsection{Research methodology}

In conducting research, it follows a descriptive/study relationship that focuses on the investigation of one of the psychological phenomena as they exist at present intending to diagnose them, revealing their aspects, and determining the relationships between their elements or between them and other phenomena [31-38]. The current research community includes all the computer departments in the colleges of education in the province of Baghdad/the morning study for the academic year (2014-2013). The sample of this research was determined intentionally, as the total community of research was divided into students of the Department of Computer Science in the Colleges of Education for Pure Sciences of the University of Baghdad, and the College of Education at the University of Al-Mustansiriya, and among the two Departments of Computer Science, students of the second stage were identified from the four stages, and within this stage were divided The sample is divided into male and female students, from which the required numbers from each category were calculated so that the proportion of the sample size drawn from each category is proportional to the size of the class in the original community. After the sample size was determined, the selection was made at random within the same category to ensure that each individual from the research community had an opportunity to be within the research sample. The number of students in the second stage of the College of Education for Pure Sciences reached (93) male and female students for morning study, distributed between (47) female students and (46) male students, while the number of students of the second stage of the College of Education/University of Al-Mustansiriya reached (187) male and female students, distributed as (83). Female students and (104) students for the morning study as well, and thus the total number of students in the two colleges is (280) male and female, of whom (150) male and (130) female students. Students who had failed in their classes from the previous year were statistically excluded to ensure that the results of the experiment were not distorted. So, the sample size, the subject of this research, is from the two colleges after excluding the repetitive students and using the equation for calculating the required sample size (200) male and female students [32].

\subsection{Research tests}

For the purpose of answering research questions and verifying their hypotheses; Two tests were required, the first to measure the decision-making skill, and the second to measure academic achievement in the subject of numerical analysis in the research sample. The final application on the research sample, to answer the research questions and verify its hypotheses, and after conducting the appropriate statistical treatments for both the decision-making skill test consisting of (14) items, and the achievement test consisting of (14) items. The two tests were applied for the period from 2/2/2014 to $26 / 2 / 2014$. It was taken into account that they are applied under appropriate environmental conditions. Thus, the data was ready for statistical analysis purposes. 


\section{$5 \quad$ Results}

\subsection{Results related to decision-making skill}

Because of the diversity of scores upon correction, that is, some questions take a degree of $(0,1)$ and questions that are corrected of (10 degrees), and this leads to a difference in the hypothetical average of the test, so the questions will be divided and unified according to the scale of each of them in this hypothesis.

Table 1. The mean and the T-value (questions (correction 1.0))

\begin{tabular}{|l|c|c|c|c|c|c|c|}
\hline $\begin{array}{c}\text { The } \\
\text { All } \\
\text { Sample }\end{array}$ & $\begin{array}{c}\text { Arithmetic } \\
\text { Mean }\end{array}$ & $\begin{array}{c}\text { Std. } \\
\text { Dev. }\end{array}$ & $\begin{array}{c}\text { Hypothetical } \\
\text { Mean }\end{array}$ & $\begin{array}{c}\text { Computed } \\
\text { T-Test } \\
\text { Value }\end{array}$ & $\begin{array}{c}\text { Tabular } \\
\text { T-Test } \\
\text { Value }\end{array}$ & $\begin{array}{c}\text { Statistical } \\
\text { Significance }\end{array}$ & $\begin{array}{c}\text { Degree } \\
\text { of } \\
\text { Freedom }\end{array}$ \\
\hline 200 & 3.63 & 0.652 & 2 & 35.35 & 1.65 & 0.05 & 199 \\
\hline
\end{tabular}

Table 2. The mean and the T-value (questions (correction of 10))

\begin{tabular}{|l|c|c|c|c|c|c|c|}
\hline $\begin{array}{c}\text { The } \\
\text { All } \\
\text { Sample }\end{array}$ & $\begin{array}{c}\text { Arithmetic } \\
\text { Mean }\end{array}$ & $\begin{array}{c}\text { Std. } \\
\text { Dev. }\end{array}$ & $\begin{array}{c}\text { Hypothetical } \\
\text { Mean }\end{array}$ & $\begin{array}{c}\text { Computed } \\
\text { T-Test } \\
\text { Value }\end{array}$ & $\begin{array}{c}\text { Tabular } \\
\text { T-Test } \\
\text { Value }\end{array}$ & $\begin{array}{c}\text { Statistical } \\
\text { Significance }\end{array}$ & $\begin{array}{c}\text { Degree } \\
\text { of } \\
\text { Freedom }\end{array}$ \\
\hline 200 & 89.795 & 7.795 & 55 & 63.13 & 1.65 & 0.05 & 199 \\
\hline
\end{tabular}

We find that the measures for which the mean of arithmetic is more significant than the hypothesis, which implies that sample students have the decision-making skill that represents one of the higher thinking skills. To test the null hypothesis, "there is no statistically significant difference at the level of significance $(0.05)$ between the average true performance and the average hypothesis performance of the sample students on the decision-making skill test". This supports the conclusion, mainly because the sample is made up of students from the second stage students in the computer science departments in the colleges of education in Baghdad governorate who have logical thinking and their responses are commensurate with situations.

Table 3. The results of the T-test to measure the significance of the difference between the average real and hypothetical performance of the research sample students

\begin{tabular}{|l|c|c|c|c|c|c|c|c|}
\hline $\begin{array}{c}\text { Size } \\
\text { of } \\
\text { Sample }\end{array}$ & Mean & $\begin{array}{c}\text { St. } \\
\text { Div. }\end{array}$ & $\begin{array}{c}\text { Std. } \\
\text { Error }\end{array}$ & Variance & $\begin{array}{c}\text { Calculated } \\
\text { T-Value }\end{array}$ & $\begin{array}{c}\text { Scheduled } \\
\text { T-Value }\end{array}$ & $\begin{array}{c}\text { Degree } \\
\text { Freedom }\end{array}$ & $\begin{array}{c}\text { Statistical } \\
\text { Significance }\end{array}$ \\
\cline { 1 - 5 } $\begin{array}{l}\text { Male } \\
(97)\end{array}$ & 89.433 & 8.275 & 0.090 & 76.597 & 7.876 & 1.65 & 198 & 0.05 \\
\cline { 1 - 4 } $\begin{array}{l}\text { Female } \\
(103)\end{array}$ & 97.185 & 4.673 & 0.045 & 21.836 & & & & \\
\hline
\end{tabular}

It is noted from the above table that the calculated " $\mathrm{t}$ " value is greater than the tabular " $t$ " value, and this leads us to reject the null hypothesis. That is, "there is a difference between the average scores of male and female students' performance on the decision-making skill test that was prepared for this research", and the result was in 
favor of the female students. The reason may be that the decision-making skill depends on experience and the accumulation of experience in choosing the appropriate alternative from among the alternatives offered, and this is owned by students through study and reading. It is known that female students are more studied than male students and therefore have more experience than male students.

\subsection{Results related to academic achievement}

Because of the diversity of scores upon correction, that is, some questions take $(0,1)$ degrees, and questions that are corrected of (6 degrees), which leads to a difference in the hypothetical average of the test, so the questions will be divided and unified according to each of them in this hypothesis as follows:

Table 4. The mean and the T-value (questions (correction 1.0))

\begin{tabular}{|l|c|c|c|c|c|c|c|}
\hline $\begin{array}{c}\text { The } \\
\text { All } \\
\text { Sample }\end{array}$ & $\begin{array}{c}\text { Arithmetic } \\
\text { Mean }\end{array}$ & $\begin{array}{c}\text { Std. } \\
\text { Dev. }\end{array}$ & $\begin{array}{c}\text { Hypothetical } \\
\text { Mean }\end{array}$ & $\begin{array}{c}\text { Computed } \\
\text { T-test } \\
\text { Value }\end{array}$ & $\begin{array}{c}\text { Tabular } \\
\text { T-test } \\
\text { Value }\end{array}$ & $\begin{array}{c}\text { Statistical } \\
\text { Significance }\end{array}$ & $\begin{array}{c}\text { Degree } \\
\text { of } \\
\text { Freedom }\end{array}$ \\
\hline 200 & 7.45 & 1.686 & 2 & 28.943 & 1.65 & 0.05 & 199 \\
\hline
\end{tabular}

Table 5. The mean and the T-value (questions (correction of 6 marks))

\begin{tabular}{|l|c|c|c|c|c|c|c|}
\hline $\begin{array}{c}\text { The } \\
\text { All } \\
\text { Sample }\end{array}$ & $\begin{array}{c}\text { Arithmetic } \\
\text { Mean }\end{array}$ & $\begin{array}{c}\text { Std. } \\
\text { Dev. }\end{array}$ & $\begin{array}{c}\text { Hypothetical } \\
\text { Mean }\end{array}$ & $\begin{array}{c}\text { Computed } \\
\text { T-test } \\
\text { Value }\end{array}$ & $\begin{array}{c}\text { Tabular } \\
\text { T-test } \\
\text { Value }\end{array}$ & $\begin{array}{c}\text { Statistical } \\
\text { Significance }\end{array}$ & $\begin{array}{c}\text { Degree } \\
\text { of } \\
\text { Freedom }\end{array}$ \\
\hline 200 & 24.395 & 4.071 & 21 & 11.794 & 1.65 & 0.05 & 199 \\
\hline
\end{tabular}

We note in Both Tables $(4,5)$ that the arithmetic mean is higher than the hypothetical average, and this means that the results were in favor of the students.

Table 6. The results of the T-test to measure the significance of the difference between the average real and hypothetical performance of the research sample students

\begin{tabular}{|l|c|c|c|c|c|c|c|c|}
\hline $\begin{array}{c}\text { Size } \\
\text { of } \\
\text { Sample }\end{array}$ & Mean & $\begin{array}{c}\text { St. } \\
\text { div. }\end{array}$ & $\begin{array}{c}\text { Std. } \\
\text { Error }\end{array}$ & Variance & $\begin{array}{c}\text { Calculated } \\
\text { T-Value }\end{array}$ & $\begin{array}{c}\text { Scheduled } \\
\text { T-Value }\end{array}$ & $\begin{array}{c}\text { Degree } \\
\text { Freedom }\end{array}$ & $\begin{array}{c}\text { Statistical } \\
\text { Significance }\end{array}$ \\
\cline { 1 - 6 } $\begin{array}{l}\text { Male } \\
(97)\end{array}$ & 29.021 & 6.086 & 0.062 & 37.039 & 8.385 & 1.65 & 198 & 0.05 \\
\cline { 1 - 5 }$(103)$ & 34.505 & 2.574 & 0.024 & 6.625 & & & \\
\hline
\end{tabular}

It is noted from the above table that the calculated " $t$ " value is higher than the tabular " $t$ " value at the significance level $(0.05)$, which means "there is a difference between the performance of male and female students from the research sample contains the achievement test that was prepared for the aforementioned purpose", and this supports the conclusion reached previously. Observing the results of the ministerial exams for recent years clearly shows the high achievement of female students. It is also noted that 
the top students in the country and for the previous five years in a row are female students. (Statistics Division in the Ministry of Education) and [33] indicates that socialization in our society pushes the student to stick to the study and diligence in it as a compensatory behavior, as indicates that the achievement of female students often comes "through the need for social appreciation, which is an important need for female students". Therefore, this motivation makes female students accept towards learning diligently. In addition, some studies proved that female students outperform male students in the study, especially that depends on language abilities, memory, and speed of perception.

\subsection{Results related to the correlation between decision-making skill and academic achievement}

Table 7. Correlation coefficients between decision-making skill $\&$ academic achievement and the significance of correlation when at research sample

\begin{tabular}{|c|c|c|c|c|c|}
\hline Relation & Correlation & $\begin{array}{c}\text { The Computed } \\
\text { T-Value of the } \\
\text { Correlation } \\
\text { Coefficient }\end{array}$ & $\begin{array}{c}\text { The } \\
\text { Tabular } \\
\text { T Value }\end{array}$ & $\begin{array}{c}\text { The } \\
\text { Degree of } \\
\text { Freedom }\end{array}$ & $\begin{array}{c}\text { Indication } \\
\text { Level }\end{array}$ \\
\hline $\begin{array}{l}\text { Academic achievement with } \\
\text { decision making skill }\end{array}$ & 0.24 & 3.48 & 1.96 & 198 & 0.05 \\
\hline
\end{tabular}

The measured value of $\mathrm{T}$ is greater than the tabular value of $\mathrm{T}$ at a meaning level (0.05), this means a positive correlation coefficient between Decision-making skills and the samples' Academic achievement. In other words, the two variables are highly directly correlated. This speech is rational since it is understood that the top of the mathematical pyramid is problem-solving, it is known that the top of the pyramid in mathematics is problem-solving and achievement is problem-solving and this is part of decision making, and therefore the existence of a correlation between them is normal.

Table 8. Correlation coefficients between decision-making skill \& academic achievement and the significance of correlation when at research sample

\begin{tabular}{|l|c|c|c|c|c|}
\hline \multicolumn{1}{|c|}{ Relation } & $\begin{array}{c}\text { Correlation } \\
\text { Coefficient }\end{array}$ & $\begin{array}{c}\text { The Computed } \\
\text { T-Value of the } \\
\text { Correlation } \\
\text { Coefficient }\end{array}$ & $\begin{array}{c}\text { The } \\
\text { Tabular } \\
\text { T Value }\end{array}$ & $\begin{array}{c}\text { The } \\
\text { Degree of } \\
\text { Freedom }\end{array}$ & $\begin{array}{c}\text { Indication } \\
\text { Level }\end{array}$ \\
\hline $\begin{array}{l}\text { Academic achievement } \\
\text { with decision making } \\
\text { skill (male) }\end{array}$ & 0.02 & 0.28 & 1.96 & 95 & 0.05 \\
\hline
\end{tabular}

Referring to the above table, it is noted that the value of the calculated correlation coefficient between the decision-making skill and the academic achievement of the research sample scores $(0.02)$, and this is a very weak positive correlation coefficient and that the calculated t-value (0.28) is smaller than the tabular t-value (1.96) at the significance level (0.05). This indicates the acceptance of the previous null hypothesis regarding decision-making skill and its relationship to achievement. That is, there is no correlation between the two variables, among the students of the research sample, and 
the opinions of several mathematics professors and those with no less than (10) years of teaching experience were consulted, and their opinion was clear that students are usually characterized by indifference in the study in general, and this is reflected in their expertise in making the right decision.

Table 9. Correlation coefficients between decision-making skill \& academic achievement and the significance of correlation when at research sample

\begin{tabular}{|l|c|c|c|c|c|}
\hline \multicolumn{1}{|c|}{ Relation } & $\begin{array}{c}\text { Correlation } \\
\text { Coefficient }\end{array}$ & $\begin{array}{c}\text { The Computed } \\
\text { T-Value of the } \\
\text { Correlation } \\
\text { Coefficient }\end{array}$ & $\begin{array}{c}\text { The } \\
\text { Tabular } \\
\text { T Value }\end{array}$ & $\begin{array}{c}\text { The Degree } \\
\text { of Freedom }\end{array}$ & $\begin{array}{c}\text { Indication } \\
\text { Level }\end{array}$ \\
\hline $\begin{array}{l}\text { Academic achievement } \\
\text { with decision making } \\
\text { skill (female) }\end{array}$ & -0.21 & 3.02 & 1.96 & 101 & 0.05 \\
\hline
\end{tabular}

Referring to the above table, it is noted that the value of the calculated correlation coefficient between the decision-making skill and the academic achievement of the scores of the research sample of female students $(-0.21)$, which is a negative and weak correlation coefficient, and that the calculated $\mathrm{T}$ value of the correlation coefficient (3.02), which is greater than the tabular value (1.96). at the significance level (0.05). This indicates the rejection of the previous null hypothesis regarding the decision-making skill and its relationship to achievement, that is: there is a correlation between the two variables, but it is an inverse relationship, that is, whenever one of the variables increases, a decrease in the other may be due. Basic like the rest of the specialization lessons, and the student, by nature, focus on achievement tests because he waits for the degree as a basis for passing through to success more than his interest and focus on decision-making tests or other thinking skills.

\section{Conclusion}

1. Students of the computer science departments in colleges of education in the province of Baghdad possess the skill of decision-making compared to the hypothetical average with which they were compared. Whereas, females outperformed males in the decision-making skill test that was prepared for the research.

2. Females outperform males in the achievement test for numerical analysis.

3. There is a correlation between the decision-making skill and the academic achievement of the students as a whole.

4. There is no correlation between decision-making skills and male academic achievement. While there is an inverse correlation between the decision-making skill and the achievement of female students. 
1. Exerting more efforts to make training in thinking skills a joint task of the family and educational environments, so that it leads learners to take the initiative and inquire about their surroundings and express topics, issues, and events.

2. Conducting courses related to thinking and its skills for professors and those who carry out the teaching process in colleges and institutes to measure the degree of their possession of these skills, and the degree of their teaching practices to work on developing them among students.

\section{References}

[1] J. Fathi. "Teaching thinking, concepts, and applications" 3rd edition, Dar Al-Fikr, Amman., 2007.

[2] Al-Mayouf, Rafid and Areej, Khader Hassan "Problematization and Research as a Method of Teaching Mathematics," Anbar University Journal for Human Sciences, vol. 3, Iraq., 2012.

[3] D. Abdul-Rahman Al-Malah, H. Jinah, H. ALRikabi, "Enhancement of educational services by using the internet of things applications for talent and intelligent schools," Periodicals of Engineering and Natural Sciences (PEN), vol. 8, no. 4, pp. 2358-2366, 2020.

[4] M. Nofal, "Teaching Thinking, Theory and Application," 3rd edition, Dar Al Masirah, Amman., 2009.

[5] D. Adshead, S. Thacker, L. I. Fuldauer, and J. Hall, "Delivering on the Sustainable Development Goals through Long-term Infrastructure Planning," vol. 59, p. 101975, 2019. https:// doi.org/10.1016/j.gloenvcha.2019.101975

[6] H. Alrikabi, "Enhanced Data Security of Communication System using Combined Encryption and Steganography," International Journal of Interactive Mobile Technologies, vol. 15, no. 16, pp. 144-157, 2021. https://doi.org/10.3991/ijim.v15i16.24557

[7] B. H. Majeed, L. F. Jawad, H. Alrikabi, "Tactical Thinking and its Relationship with Solving Mathematical Problems among Mathematics Department Students," International Journal of Emerging Technologies in Learning (iJET), vol. 16, no. 9, 2021. https://doi.org/10.3991/ijet. v16i09.22203

[8] E. Bolisani and C. Bratianu, Emergent Knowledge Strategies: Strategic Thinking in Knowledge Management. Springer, 2017. https://doi.org/10.1007/978-3-319-60657-6

[9] Jonassen, David H., "Toward a design theory of problem solving," Educational Technology Research and Development, vol. 48, no. 4, pp. 63-85, 2000. https://doi.org/10.1007/ $\underline{B F 02300500}$

[10] B. H. Majeed, "Mathematical Logical Intelligence and its Relationship with Achievement among College of Education Students in Baghdad Governorate," Nasaq, 1(2), 2014.

[11] B. H. Majeed, "Mathematical Logical Intelligence and Decision-Making Skills and Their Relationship with the Students Achievement at Colleges of Education Students in the Province of Baghdad," 2014.

[12] S. Rivkin, Teachers, Schools, and Academic Achievement Ecomomtrica, 73(2):20-90, 2010 https://doi.org/10.1111/j.1468-0262.2005.00584.x 
[13] H. T. Salim, A. Nabaa Ali Jasim, "Design and Implementation of Smart City Applications Based on the Internet of Things," International Journal of Interactive Mobile Technologies (iJIM), vol. 15, no. 13, pp. 4-15, 2021. https://doi.org/10.3991/ijim.v15i13.22331

[14] J. Cai and S. Hwang, "Learning to Teach through Mathematical Problem Posing: Theoretical Considerations, Methodology, and Directions for Future Research," International Journal of Educational Research, vol. 102, p. 101391, 2020. https://doi.org/10.1016/j.ijer.2019.01.001 $[15]$

[16] N. A. Jasim, H. T. S. AlRikabi, and M. S. Farhan, "Internet of Things (IoT) Application in the Assessment of Learning Process," in IOP Conference Series: Materials Science and Engineering, 2021, vol. 1184, no. 1, p. 012002: IOP Publishing. https://doi. org/10.1088/1757-899X/1184/1/012002

[17] M. T. Chi, R. Glaser, and E. Rees, "Expertise in problem solving," Pittsburgh Univ PA Learning Research and Development Center, 1981.

[18] E. Care, P. Griffin, C. Scoular, N. Awwal, and N. Zoanetti, "Collaborative Problem Solving Tasks," in Assessment and Teaching of 21st Century Skills: Springer, 2015, pp. 85-104. https://doi.org/10.1007/978-94-017-9395-7 4

[19] S. Cottrell, Critical Thinking Skills: Effective Analysis, Argument and Reflection. Macmillan International Higher Education, 2017. https://doi.org/10.1057/978-1-137-55052-1

[20] D. Tall, "The Psychology of Advanced Mathematical Thinking," in Advanced Mathematical Thinking: Springer, 2002, pp. 3-21. https://doi.org/10.1007/0-306-47203-1_1

[21] A. Ghanizadeh, A. H. Al-Hoorie, and S. Jahedizadeh, Higher Order Thinking Skills in the Language Classroom: A Concise Guide. Springer, 2020. https://doi.org/10.1007/ 978-3-030-56711-8

[22] L. F. Jawad, B. H. Majeed, and H. T. ALRikabi, "The Impact of Teaching by using STEM Approach in the Development of Creative Thinking and Mathematical Achievement among the Students of the Fourth Scientific Class," iJIM, vol. 15, no. 13, pp. 172-188, 2021. https:// doi.org/10.3991/ijim.v15i13.24185

[23] T.-C. Hsu, S.-C. Chang, Y.-T.J.C. Hung, and Education, "How to Learn and How to Teach Computational Thinking: Suggestions Based on a Review of the Literature," vol. 126, pp. 296-310, 2018. https://doi.org/10.1016/j.compedu.2018.07.004

[24] T. Buzan, Mind Map Mastery: The Complete Guide to Learning and using the most Powerful Thinking Tool in the Universe. Watkins Media Limited, 2018.

[25] L. F. Jawad, B. H. Mjeed, and H. T. ALRikabi, "The Impact of CATs on Mathematical Thinking and Logical Thinking among Fourth-Class Scientific Students," International Journal of Emerging Technologies in Learning (iJET), vol. 16, no. 10, pp. 172-188, 2021. https://doi.org/10.3991/ijet.v16i10.22515

[26] L. Verschaffel, S. Schukajlow, J. Star, and W.J.Z. Van Dooren, "Word Problems in Mathematics Education: A Survey," vol. 52, no. 1, pp. 1-16, 2020. https://doi.org/10.1007/ s11858-020-01130-4

[27] B. H. Majeed, and A. Kh. Hussain, "The Impact of Reflexive Learning Strategy on Mathematics Achievement by First Intermediate Class Students and their Attitudes Towards E-Learning," Turkish Journal of Computer and Mathematics Education (TURCOMAT), vol. 12, no. 7, pp. 3271-3277, 2021.

[28] B. H. Majeed, "The Relationship between Conceptual Knowledge and Procedural Knowledge among Students of the Mathematics Department at the Faculty of Education for Pure Sciences/IBn Al-Haitham, University of Baghdad," International Journal of Innovation, Creativity and Change, vol. 12, no. 4, pp. 333-346, 2020.

[29] L. F. Jawad, M. K. Raheem, and B. H. Majeed, "The Effectiveness of Educational Pillars Based on Vygotsky's Theory in Achievement and Information Processing among First Intermediate Class Students," International Journal of Emerging Technologies in Learning, vol. 16, no. 12, pp. 246-262, 2021. https://doi.org/10.3991/ijet.v16i12.23181 
[30] G. S. Goloshumova, O. V. Ershova, V. B. Salakhova, A. V. Kidinov, S. A. Nalichaeva, and V. A. J. E. j.o.b. Yanysheva, "Information and Educational Environment of Higher School as a Factor of the Formation of Coping Strategies in the Structure of Students' Personality (Ecological and Psychological Aspect)," vol. 13, no. 2, pp. 1867-1874, 2019.

[31] R. B. AlMayouf, B. H. Majeed, "Logical Mathematical Intelligence and its Relationship to the Skill of Decision-Making among Students of Colleges of Education in Baghdad Governorate," 2018.

[32] D. Al-Malah, H. Salim, and H. Mutar, "Cloud Computing and its Impact on Online Education," IOP Conference Series: Materials Science and Engineering, vol. 1094, p. 012024 , 2021. https://doi.org/10.1088/1757-899X/1094/1/012024

[33] A. Alaidi, O. Yahya, and H. Alrikabi, "Using Modern Education Technique in Wasit University," International Journal of Interactive Mobile Technologies, vol. 14, no. 6, pp. 82-94, 2020. https://doi.org/10.3991/ijim.v14i06.11539

[34] N. Al-zubidi, R. K. Hasoun, S. H. Hashim, and H. TH. "Mobile Application to Detect Covid-19 Pandemic by using Classification Techniques: Proposed System,” International Journal of Interactive Mobile Technologies, vol. 15, no. 16, 2021. https://doi.org/10.3991/ ijim.v15i16.24195

[35] A. Ssalah, R. Khairy, H. ALRikabi, “The Detection of Counterfeit Banknotes using Ensemble Learning Techniques of AdaBoost and Voting," International Journal of Intelligent Engineering and Systems, vol. 14, no. 1, pp. 326-339, 2021. https://doi.org/10.22266/ ijies2021.0228.31

[36] H. F. Khazaal, H. T. S. ALRikabi, T. Dagiuklas, S. Kotsopoulos, "A Proposed Model for the Mutual Dependency Between QoE and QoS in Wireless Heterogeneous Networks," Journal of Al-Qadisiyah for Computer Science and Mathematics, vol. 9, no. 2, pp. 45-55, 2017. https://doi.org/10.29304/jqcm.2017.9.2.312

[37] B. K. Mohammed, S. A. A. A. Alsaidi, R. F. Chisab, and H. T. S. AlRikabi, "Efficient RTS and CTS Mechanism which Save Time," International Journal of Interactive Mobile Technologies, Article vol. 14, no. 4, pp. 204-211, 2020. https://doi.org/10.3991/ijim.v14i04.13243

[38] H. T. Salim, A. H. M. Alaidi, and F. T. Abed, "Attendance System Design and Implementation Based on Radio Frequency Identification (RFID) and Arduino," Journal of Advanced Research in Dynamical Control Systems, vol. 10, no. SI4, pp. 1342-1347, 2018.

\section{Author}

Ban Hassan Majeed, she is presently the lecturer and one of the faculty of the computer department, College of Education for Pure Sciences/Ibn Al-Haitham, University of Baghdad, Iraq. Her current research interests include methods of teaching mathematics, thinking and it's skills, educational technology, digital education, teaching strategies with e-learning strategies, multiple Intelligences in teaching and learning, technological innovations. Email: ban.h.m@ihcoedu.uobaghdad.edu.iq

Article submitted 2021-08-19. Resubmitted 2021-10-17. Final acceptance 2021-10-24. Final version published as submitted by the authors. 